\title{
Oral Health Status and Treatment Needs of Visual Impairment in Phitsanuloke, Thailand
}

\author{
Patcharaphol Samnieng ${ }^{1}$, Pakinai Seehaumpai ${ }^{2}$, Supattra Wichachai ${ }^{2}$, Patcharawan \\ Yusookh ${ }^{2}$
}

${ }^{1}$ Department of Preventive Dentistry, Faculty of Dentistry, Naresuan University, Phitsanulok Thailand. ${ }^{2}$ Faculty of Dentistry, Naresuan University, Phitsanuloke 65000, Thailand

Correspondinge-mail to: patcharaphols@yahoo.com

\begin{abstract}
There is little information on the oral health status of visual impairment in Thailand. Objective: To investigate the oral health status and dental treatment needs of visual impaired Thai. Method: The subjects were 146 visual impairment (70 males and 76 females, mean age $48.8 \pm 5.9$ ), who live in Phitsanuloke, Thailand. Information on self-perceived oral health problems, oral function and oral health behavior was obtained via questionnaires. Oral examinations investigated the Decay Missing Filling Teeth (DMFT), Simplified Oral Hygiene Index (OHIS) and prosthetic needs index. Results: The mean DMFT score was 16.0 (DT=4.4, MT=10.2, FT=1.4), the mean number of teeth present was $15.5 .35 \%$ of subjects needed dental fillings and $12.3 \%$ required tooth extractions. $34.8 \%$ had periodontal disease and mean OHIS score were 2.52. Thirty-eight percent of subjects need both upper and lower partial dentures. Visual impaired suffer from oral function problems (speaking problem 26.5\%, swallowing problem $32.6 \%$, tasting problem $29.2 \%$ and chewing problem $45.2 \%$ ). Conclusion: The oral health status of visual impairment was poor due to high levels of tooth loss, caries experience and periodontal disease. Therefore, it is important to have a proper preventive approach and service delivery programs to improve the oral health condition of this population.
\end{abstract}

\begin{abstract}
ABSTRAK
Kebutuhan perawatan dan status kesehatan gigi dan mulut tuna netra di Phitsanuloke, Thailand. Tidak banyak informasi mengenai status kesehatan gigi dan mulut pada tuna netra di Thailand. Tujuan: Menganalisa status dan kebutuhan perawatan kesehatan gigi dan mulut pada tuna netra di Thailand. Metode: Subjek penelitian ini adalah 146 tuna netra (70 laki-laki dan 76 perempuan dengan rerata umur 48,8 $\pm 5,9$ ) yang bertempat tinggal di Phitsanuloke, Thailand. Kuesioner digunakan untuk mendapatkan informasi mengenai persepsi subjektif masalah kesehatan gigi dan mulut, fungsi oral dan perilaku. Pemeriksaan oral dilakukan untuk menganalisa Decay Missing Filling Teeth (DMFT), Simplified Oral Hygiene Index (OHIS) dan prosthetic needs index. Hasil: Rerata DMFT subjek yang diperiksa adalah $16(\mathrm{DT}=4,4, \mathrm{MT}=10,2, \mathrm{FT}=1,4)$, rerata jumlah gigi yang masih ada 15,5. 35\% memerlukan tambalan gigi dan 12,3\% membutuhkan pencabutan gigi. 34,8\% memiliki penyakit periodontal dengan rerata OHIS 2,52. 38\% subjek membutuhkan gigi tiruan sebagian atas dan bawah. Tuna netra mengalami masalah fungsi oral (masalah dalam berbicara 26,5\%, masalah penelanan 32,6\%, masalah pengecapan 29,2\% dan masalah pengunyahan $45,2 \%$ ). Simpulan: Status kesehatan gigi dan mulut tuna netra rendah karena kehilangan gigi yang banyak, karies dan penyakit periodontal. Oleh karena itu sangatlah penting untuk memliki pendekatan program preventif yang tepat utnuk meningkatkan kesehatan gigi dan mulut populasi tersebut.
\end{abstract}

Key words: DMFT, oral health status, treatment needs, visual impairment 


\section{INTRODUCTION}

Oral health is linked to good general health and happiness, and there is evidence that esthetically acceptable and functionally adequate dentitions affect self-esteem, confidence, and socialization. ${ }^{1}$ Vision may be the most important sense for interpreting the world around us, and when sight is impaired, it can have detrimental effects on physical, neurological, cognitive, and emotional development. Visual impairments vary from total blindness to slight limitations of size, color, distance, and shape. ${ }^{2}$ Visual impairment relates to a person's eyesight which cannot be corrected to normal vision. ${ }^{3}$ Physical, social and information are barriers that impact on oral health of visual impairment. ${ }^{4}$ Visual impairments tended to have a larger amount of dental plaque and were at a higher risk for dental diseases than were sighted individuals. ${ }^{5}$

Oral health and dental care of the disabled has generally been poorer than the general population. ${ }^{6}$ High DMFT/ $\mathrm{dmft}$ scores were manifest in groups of visually impaired children in many countries. ${ }^{7,8}$ Poor oral hygiene, gingivitis and periodontal diseases have been reported among visually impaired children in studies from India, Iran, and Turkey., ${ }^{910}$ Inability to visualize the plaque on tooth surfaces resulting in inadequate plaque removal and therefore the progression of dental caries and inflammatory disease of the periodontium of visual impaired patients. ${ }^{7,11}$

There is little information on the oral health status of visual impairment in Thailand. The oral health status of visual impairments should be investigated so their health care needs can be determined and preventive dental procedures can be implemented. Therefore, the purpose of the present study was to investigate the oral health status and treatment needs of visual impaired Thai.

\section{METHODS}

The subjects for this cross-sectional study were drawn from visual impaired people aged 20 years or older with a simple sampling form Phitsanulok, Thailand. A total of 146 people (70 males and 76 females; mean age $=48.8$ years; $S D=6.9$ ) agreed to join the study and finger printed the informed consent form. A questionnaire survey administered by interview and oral examination were conducted. This study protocol was approved by the Naresuan University Ethical Committee on Human Rights, Thailand.

\section{Oral Function}

Oral function was evaluated by the response to the following questions: "Do you have, or have you had, speaking problems"? (swallow problem, taste problem, and chewing problem). The interviewer asked participants to respond to each question by "yes" or "no".

\section{Oral examination}

The examination procedures, instruments and diagnostic criteria followed those recommended by the World Health Organization. Tooth status was recorded using the DMFT index. The community periodontal index (CPI) was used to assess the periodontal status. In addition, prosthetic status and treatment needs were classified and recorded according to WHO criteria. Oral hygiene was assessed using the Simplified Oral Hygiene Index (OHI-S) of Green and Vermillon (1964). ${ }^{12}$

\section{Salivary flow rate}

All subjects abstained from smoking, eating and drinking for 2 hours prior to the measurement of salivary flow rate. ${ }^{13}$ Resting whole saliva was collected for 5 minutes by a spitting method. Stimulated whole saliva was collected by a mastication method, in which subjects were asked to chew a small paraffin block for 5 minutes. Subjects were classified into 2 groups according to salivary flow rates. Subjects whose resting salivary flow rate less than $0.1 \mathrm{~mL} / \mathrm{min}$ and stimulated flow rate less than $0.5 \mathrm{~mL} / \mathrm{min}$ were classified as hyposalivation.

Statistical analyses were performed with the SPSS 17 software program and $p<0.05$ accepted as the level for statistical significance. The Chi-square test was used to compare categorical or nominal level data. Analysis of variance (ANOVA) was used to test for differences of mean scores among two or more independent groups of interval level data.

\section{RESULTS}

The number of subjects aged 20-69 years was 120 $(82.19 \%)$ and those aged 60 years and older were 26 (17.81\%). Among all subjects, $39.8 \%$ of those lived with only husband or wife, $56.1 \%$ lived with their family members, and $4.1 \%$ lived alone. Most subjects were non smokers (97.3\%). Systemic diseases were observed in $77.2 \%$ of subjects: hypertension $47.3 \%$, diabetes mellitus $26.3 \%$, heart disease $7.5 \%$ and other disease $11.7 \%$. Moreover $74.9 \%$ of subjects routinely used medicines. The oral hygiene practices of subjectswere: $38.4 \%$ claimed to brush their teeth once a day, $61.6 \%$ claimed to brush their teeth twice or more per day. $32.1 \%$ of all subjects never visited dentist, only $13.2 \%$ of subjects had regular dental check ups.

The numbers of present teeth, decayed teeth and filled teeth by age and gender were showed in Table 1. Subjects in the 60 years and older age group had significantly lower number of present teeth than those in the 20-59 years old age group. The mean number of filled teeth was low and less than 2 tooth among all subjects. The mean OHIS score of this study was 2.52. One-third of subjects $(34.37 \%)$ had periodontal disease. 
Table 1. Distribution of number of teeth, decayed teeth, filled teeth, periodontal disease and OHIS of subjects

\begin{tabular}{rrrrrrr}
\hline Age (years) & Gender & $\begin{array}{c}\text { Number of teeth } \\
\text { (teeth/subject) }\end{array}$ & Decayed Teeth & Filled Teeth & Periodontal disease & OHIS \\
\hline \multirow{3}{*}{$20-59$} & Male & $18.8 \pm 6.2$ & $5.6 \pm 2.3$ & $1.4 \pm 1.6$ & $10.29 \%$ & 2.40 \\
& Female & $20.4 \pm 5.5$ & $4.6 \pm 2.5$ & $1.6 \pm 1.8$ & $2.94 \%$ & 2.18 \\
& Total & $19.2 \pm 5.7$ & $4.8 \pm 2.4$ & $1.5 \pm 1.8$ & $13.23 \%$ & 2.29 \\
$60+$ & Male & $13.7 \pm 4.4$ & $3.6 \pm 3.2$ & $0.2 \pm 0.9$ & $5.88 \%$ & 3.91 \\
& Female & $14.6 \pm 5.4$ & $2.8 \pm 2.2$ & $0.3 \pm 2.2$ & $5.88 \%$ & 2.55 \\
& Total & $13.9 \pm 5.2$ & $3.0 \pm 2.5$ & $0.3 \pm 1.9$ & $11.76 \%$ & 3.16 \\
All Subjects & Male & $16.9 \pm 7.2$ & $4.6 \pm 2.7$ & $1.3 \pm 1.3$ & $5.88 \%$ & 3.91 \\
& Female & $18.4 \pm 6.8$ & $4.3 \pm 2.4$ & $1.5 \pm 2.0$ & $5.88 \%$ & 2.55 \\
& Total & $17.8 \pm 6.9$ & $4.4 \pm 2.5$ & $1.4 \pm 1.9$ & $11.76 \%$ & 3.16 \\
\hline
\end{tabular}

Table 2. Distribution of dental treatment needs of visual impairment

\begin{tabular}{|c|c|c|c|c|c|c|c|c|c|}
\hline \multirow[b]{2}{*}{ Age (years) } & \multirow[b]{2}{*}{ Gender } & \multicolumn{3}{|c|}{ Dentition treatment need } & \multicolumn{2}{|c|}{ Periodontaltreatment need } & \multicolumn{3}{|c|}{ Prosthetic treatment need } \\
\hline & & $\underset{\%}{\text { filling }}$ & $\underset{\%}{\mathrm{RCT}}$ & $\underset{\%}{\text { Extraction }}$ & $\begin{array}{c}\text { Scaling } \\
\%\end{array}$ & $\begin{array}{c}\text { professional } \\
\text { treatment } \\
\%\end{array}$ & $\underset{\%}{\text { upper }}$ & $\begin{array}{c}\text { Lower } \\
\%\end{array}$ & $\begin{array}{c}\text { Both } \\
\%\end{array}$ \\
\hline \multirow[t]{3}{*}{$20-69$} & Male & 45.3 & 4.2 & 8.1 & 16.5 & 37.7 & 3.5 & 5.9 & 38.8 \\
\hline & Female & 41.9 & 8.0 & 14.2 & 16.0 & 41.7 & 2.6 & 7.4 & 32.0 \\
\hline & Total & 42.9 & 6.0 & 12.2 & 16.1 & 40.7 & 2.8 & 7.1 & 33.7 \\
\hline \multirow[t]{3}{*}{$60+$} & Male & 32.8 & 3.7 & 8.1 & 13.7 & 31.5 & 5.5 & 2.7 & 30.7 \\
\hline & Female & 21.8 & 3.5 & 8.1 & 9.2 & 29.7 & 2.7 & 5.4 & 16.8 \\
\hline & Total & 25 & 3.6 & 8.1 & 10.5 & 30.6 & 3.5 & 4.7 & 20.7 \\
\hline \multirow[t]{3}{*}{ Total } & Male & 39.4 & 3.9 & 8.1 & 15.2 & 34.8 & 4.4 & 4.4 & 35.1 \\
\hline & Female & 33.3 & 6.2 & 11.2 & 13.2 & 36.8 & 2.6 & 6.6 & 35.8 \\
\hline & Total & 35.0 & 5.1 & 10.4 & 13.7 & 36.2 & 3.1 & 6.0 & 38.2 \\
\hline
\end{tabular}

Among all subjects, 32.6\% complained about swallowing problems, $26.5 \%$ had speaking problems, $29.7 \%$ complained about taste problems and $45.2 \%$ had chewing problem. Table 2 shows the percentage of subjects with tooth, periodontal and prosthetic treatment needs. About 35\% needed dental fillings and $12.3 \%$ required dental extraction. Of all subjects, $36.2 \%$ needed professional scaling and $26.6 \%$ required complex treatment for managing deep periodontal pockets. In total, 38.2\% needed both upper and lower prostheses. The mean salivary flow rate of resting saliva is $0.3 \mathrm{ml} / \mathrm{min}$ and stimulating saliva flow rate is $0.43 \mathrm{ml} /$ min. $43.8 \%$ of all subjects had hyposalivation (resting salivary flow rate $<0.1 \mathrm{ml} / \mathrm{min}$ and stimulating salivary flow rate $<0.5 \mathrm{mg} / \mathrm{min}$ ).

\section{DISCUSSION}

This is the first comprehensive oral health survey of visual impaired population in Thai. It showed that the visual impairment have high caries experience, high percentage of periodontal disease and poor oral hygiene. Oral disease represents a major health problem among individuals with disabilities. ${ }^{14}$ The prevalence and severity of oral disease among this group are higher when compared to the general population. ${ }^{15}$

The caries experience variables in this study were higher for MT, DT, and DMFT higher than those reported in the national oral health survey in $2012 .{ }^{16}$ The visually impaired people are at a greater risk to develop caries, since they are unable to see the early signs of caries such as discoloration which indicates the disease process. The difficulty in removing bacterial plaque being the main factor for development of caries, continual motivation to the correct oral hygiene procedures is fundamental in order to keep a good oral hygiene in blind patients. ${ }^{17}$ Chemical plaque control is advised in visually impaired for effective plaque control. There is utmost need of individual training in oral care and plaque control in order to reduce the prevalence of dental caries among visually impaired children. ${ }^{18}$

This study showed the high prevalence of periodontal disease. Poor periodontal health and oral cleanliness 
have been observed in children with disabilities..$^{19,20}$ These results may be related to the low physical abilities of these individuals and consequent difficulties in tooth brushing. Oral health may be affected by the followings: limited understanding on the importance of oral health management, difficulties in communicating oral health needs anticonvulsant medications that impact upon gum health, and a fear of oral health procedures..$^{21,22}$ Physical restraints and general anesthesia are commonly used to treat adults with disabilities who have fear and communication difficulties related to oral health. ${ }^{23}$

This study showed that visual impairment had poor oral hygiene, consistency with previous study. The oral hygiene of the blind population is significantly worse than in an equivalent sighted one. ${ }^{24}$ Visual impairments were less knowledgeable about their oral care and did not realize the need to have regular dental visits. ${ }^{25,26}$

This study found that visual impaired person had low salivary flow rate, might be cause of their visual problems, consistency with previous study reported that light is associated with salivary flow rate. ${ }^{27}$ Hyposalivation is a risk factor not only for dental caries and periodontal disease but also for taste disturbances, speaking problems, swallowing problems, poor chewing ability and malnutrition. ${ }^{28}$ Monitoring salivary flow is an important measure in the care of visual impairment. This will alert dentist and dental health worker to mention not only oral health problem but oral function should be concerned too. Good oral health and good oral function improve quality of life. ${ }^{29}$ Improving oral health status,increasing quality of life, adequate oral health treatment, implementing proper oral health prevention and oral promotion program especially oral function program should be set as goals for the visual impairment.

The inherent problems of and limitations imposed on patients by their sensory impairment should be aware by dental professionals. ${ }^{5}$ They should know the best ways to communicate with visually impaired patients and to make them familiar with the dental setting. Maintaining oral health is central to a high quality of life because it limits the risks of disease.

These findings reflect serious lack of access to dental treatment of visual impaired Thai. Cost of the service, transportation, lack of trained and experienced dentists were a barrier to receiving dental care. ${ }^{30}$ Other barriers to equal access to dental treatment for individuals with disabilities include inadequate facilities due to restricted financial resources and complex treatment needs requiring special care or general anaesthesia. ${ }^{31}$

Oral hygiene instruction is important for prevention and treatment of oral conditions in visual impaired patient as it provides basis for good oral health throughout life. Giving good oral instructions and tactile devices to improve the tooth-brushing skills of visual impairments is considered the most important part of oral hygiene education. ${ }^{32,33}$ Adequate oral hygiene instructions may have a positive impact on individuals' oral hygiene habits and periodontal status, thereby maintaining or improving individuals' self-esteem. ${ }^{34}$ Preventive approach is essential for these special groups of visual impairment and dentist role is very essential as he can provide proper oral health education and help theses population to live a healthy life.

\section{CONCLUSION}

The oral health status of visual impairment was poor due to high levels of tooth loss, caries experience and prevalence of periodontal pockets. Oral health and oral function amongst the visual impairment is a public health concern. There is a need to develop appropriate education and service delivery programs to improve the oral health conditions of this population. In addition, the oral hygiene habits of individuals with disabilities can be improved by close monitoring and periodic dental check-ups.

\section{REFERENCES}

1. Fiske J, Davis DM, Frances C, Gelbier S. The emotional effects of tooth loss in edentulous people. BDJ. 1998;184:90-3.

2. Titiyal JS, Pal N, Murthy GV, Gupta SK, Tandon R, Vajpayee RB, et al. Causes and temporal trends of blindness and severe visual impairment in children in schools for the blind in North India. Br J Ophthalmol. 2003;87:941-5.

3. Batshaw M. Children with Disabilities. Baltimore. Paul H. Brookes Publishing Company. 2002; p188.

4. Edwards DM, Merry, AJ. Disability part 2: Access to dental services for disabled people. A questionnaire survey of dental practices in Merseyside. BDJ. 2002;193,253-5.

5. Schembri A, Fiske J. The implications of visual impairment in an elderly population in recognizing oral disease and maintaining oral health. Spec Care Dentist. 2001;21:222-6.

6. Vignehsa H, Soh G, Lo GL, Chellappah NK. Dental health of disabled children in Singapore. Aust Dent J. 1991;36:151-6.

7. Reddy K, Sharma A. Prevalence of oral health status in visually impaired children. J Ind Soc Pedod Prev Dent. 2011;291:25-7.

8. Nandini NS. New insights into improving the oral health of visually impaired children. J Ind Soc Pedod Prev Dent. 2003;21:142-3.

9. Shetty V, Hegde AM, Bhandary S, Rai K. Oral health status of the visually impaired children-a south Indian study. J Clin Pediatr Dent. 2010;34:213-6.

10. Bekiroglu N, Acar N, Kargul B. Caries experience and oral hygiene status of a group of visually 
impaired children in Istanbul, Turkey. Oral Health Prev Dent. 2012; 10:75-81.

11. Mann J, Joseph SW, Lavie G, Carlin Y, Garfunkel AA. Periodontal treatment needs and oral hygiene for institutionalized individuals with handicapping conditions. Spec Care Dentist. 1984;4:173-6

12. Greene JC, Vermillion JR. The simplified oral hygiene index. J Am Dent Assoc. 1964;68:7-13.

13. Bergdahl M. Salivary flow and oral complaints in adult dental patients. Comm Dent Oral Epidemiol. 2000;28:59-66.

14. Faulks D, Hennequin M. Evaluation of a long-term oral health program by carers of children and adults with intellectual disabilities. Spec Care Dentist. 2000;20:199-208.

15. Beange HP. Caring for a vulnerable population: Who will take responsibility for those getting a raw deal from the health care system? Med J Aust. 1996;164:159-60

16. Dental Health Divisions, Department of Health. Report of the fifth national oral health survey in Thailand in 2011-2012. Nonthaburi: Ministry of Public Health; 2012. In Thai.

17. Yalcinkaya SE, Atalay T. Improvement of oral hygiene knowledge in a group of visually impaired students. Oral Health Prev Dent. 2006;4:243-53.

18. Ahmed MS, Jindal MK, Khan S, Hashmi SH. Oral health knowledge, practice, oral hygiene status and dental caries prevalence among visually impaired students in residential institute of Aligarh. J Dent Oral Hygiene. 2009;1:22-6.

19. Shyama M, Al-Mutawa SA, Morris RE, Sugathan T, Honkala E. Dental caries experience of disabled children and young adults in Kuwait. Comm Dent Health 2001;18:181-6.

20. Al-Qahtani Z, Wyne AH. Caries experience and oral hygiene status of blind, deaf and mentally retarded female children in Riyadh, Saudi Arabia. Odontostomatol Trop. 2004;27:37-40.

21. van Houten CM, de Jongh A, Broers DL, van der Schoof M, Resida GH. Post-academic specialties 9. Dental care of disabled children living at home. Ned Tijdschr Tandheelkd. 2007;114:129-33.

22. Lindemann R, Zaschel-Grob D, Opp S, Lewis MA, Lewis C. Oral health status of adults from a California regional center for developmental disabilities. Spec Care Dentist. 2001;21:9-14.

23. Gordon SM, Dionne RA, Snyder J. Dental fear and anxiety as a barrier to accessing oral health care among patients with special health care needs. Spec Care Dentist. 1998;18:88-92.

24. Burtner AP, Dicks JL. Providing oral health care to individuals with severe disabilities residing in the community: Alternative care delivery systems. Spec Care Dentist. 1994;14:188-93.

25. O'Donnell D, Crosswaite MA. Dental health education for the visually impaired child. J R Soc Health. 1990;110:60-1.

26. Chang CS, Shih Y. Knowledge of dental health and oral hygiene practices of Taiwanese visually impaired and sighted students. J Vis Impair Blind. 2004;98:5

27. Dong C, Dawes C. The effects of blindfolding and blindness on the unstipulated and chewing-gum stimulated flow rates of whole saliva. Archives of Oral Biology. 1995;40:771-5.

28. Samnieng P, Ueno M, Shinada K, Zaitsu T, Wright FAC, Kawaguchi Y. Association of hyposalivation with oral function, nutrition and oral health in community-dwelling elderly Thai. Comm Dent Health. 2014:3;3.

29. Slade GD, Spencer AJ. Development and evaluation of the Oral Health Impact Profile. Comm Dent Health. 1994;11:3-11.

30. Oredugba FA, Akindayomi Y: Oral health status and treatment needs of children and young adults attending a day centre for individuals with special health care needs.

BMC Oral Health. 2008, 8:30.

31. Ajami BA, Shabzendedar M, Rezay YA, Asgary M. Dental treatment needs of children with disabilities. J Dent Res Dent Clin Dent Prospects. 2007;1:2.

32. Mahoney EK, Kumar N, Porter SR. Effect of visual impairment upon oral health care: A review. BDJ. 2008;204:63-7.

33. O'Donnell D, Crosswaite MA. Dental health education for the visually impaired child. J Royal Soc Promotion Health. 1990;110: 60-1.

34. Jwani, S, Ainamo A. Periodontal conditions among the elderly: five-year longitudinal study. Spec Care Dent. 2001;21:45-51. 